\title{
The Bad Jesus: The Ethics of New Testament Ethics, by Hector Avalos
}

Bible in the Modern World 68 | Sheffield: Sheffield Phoenix Press, 20I5 | xiv + 46I pages | ISBN: 978-I-909697-737 (hardcover) £60.00 | ISBN: 978-I-909697-79-9 (softcover) $£ 25.00$

This provocative and controversial book by Hector Avalos is a sequel to his previous book Slavery, Abo-
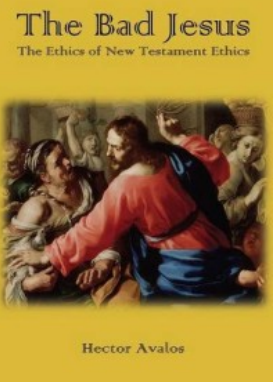
litionism, and the Ethics of Biblical Scholarship (see Peter Lineham's review in Relegere 4, no. 2 (20I4): 289-93), wherein he continues his meta-critical agenda of debunking the Christian orientation of modern biblical scholarship. In fact, its main title The Bad Jesus announces the big picture of what the author is attempting to achieve. According to the author, "bad Jesus" means that many of the ethical principles proclaimed or practiced by Jesus are antithetical to the most widely accepted founding principles of contemporary ethics, namely, the United Nations' Universal Declaration of Human Rights (UDHR). The subtitle The Ethics of New Testament Ethics, however, reveals the author's more fundamental concerns. Behind all the detailed discussions about the ethics of Jesus lies the author's meta-ethical question as to 
whether it is ethical to rely on a text or a revered figure, ancient or modern, to formulate ethics.

The origin of this book lies in the author's bafflement in reading academic literature on Christian ethics, where Jesus allegedly never does anything wrong. Hector Avalos, a self-declared New Atheist and professor of Religious Studies in Iowa State University, rejects "scholarly" attempts to idolize Jesus or render him a paradigm of modern ethics. According to the author, Jesus is a man who holds pre-scientific and imperialistic worldviews prevalent among first-century Palestinian Jews and consequently his ethical principles are flawed by modern standards. Why then do biblical scholars always portray Jesus in a positive light? Avalos answers this question essentially in two steps. First, biblical scholars' high Christology is to blame. For them, since Jesus is God, he can't be wrong. Second, even those who do not subscribe to this theological presupposition are still part of what the author calls "an ecclesial-academic complex" (280) and hence the New Testament ethicists do not give up their academic pretensions when it comes to defending Jesus as always being ethically right. Indeed, many of them do engage in historicalcritical and descriptive studies of the Gospels, but their scholarship seems to serve as an apologetic tool for their religionist agenda. To this end, the author claims to include a series of case studies in this book that are meant "to illustrate the extent to which religionism and more particularly a Christian bias still permeates what are otherwise supposed to be historical-critical descriptive studies of the ethics of Jesus" (27).

Each case study follows the same pattern of logic: Instead of proving his hypothesis for the bad Jesus, Avalos tries to disprove its opposite, namely, the good Jesus advocated by New Testament ethicists. The author's exegetical discussions, which is the meat of the book, focus on refuting positive portrayals of Jesus presented by New Testament ethicists and uncovering the religionist agenda of their academic endeavor. Avalos also brings in extra-biblical materials relevant to the issue in question in order to demonstrate either that Jesus's good ethical principle is not innovative or that his purported good principle is not good at all, when placed in its proper historical context. By so doing, Avalos wants to disabuse the readers of the idea that non-Christian oriental cultures are not ethically innovative or not as humane as Christianity. The book ends with an appendix meant to show New Testament ethicists' ignorance of non-Christian literatures, an extensive bibliography, and two indices of references and authors.

To be more specific, chapters 2 through 6 deal with ethical qualities of 
human interrelations such as love, hate, violence, and social hierarchies. In chapters 2 and 3, in particular, the author argues that the love Jesus advocates is neither selfless nor inclusive, but may entail hateful violence, when properly understood in the context of an ancient vassal treaty. Love in that context is equivalent to obeying the superior's directives, irrespective of what they entail. Chapters 4 and 5 address the issue of violence. While Christian pacifists portray Jesus as being non-violent, the author shows that Jesus takes full advantage of violence for his imperialistic agenda. Even those passages where Jesus seems to oppose violence should be understood as "deferred violence" (violence meant to be performed at a future time: cf. Matt 25:4I-46) in mind. "Non-violence should refer to the repudiation of violence in any form and under any circumstances," the author adds (IOI). In chapter 6, which addresses social hierarchies, Avalos claims that just because Jesus is opposed to the Roman empire does not make him an egalitarian or an antiimperialist, instead, Jesus simply replaces the Roman empire with another empire called the Kingdom of God. He maintains a hierarchy among his disciples, not to mention his exculpatory attitude toward slavery.

Chapters 7 through io address Jesus's attitude toward specific groups of people: namely, Jews, the poor, women, and the disabled and Avalos calls Jesus anti-Jewish, anti-poor, misogynistic, and anti-disabled. He goes so far as to compare Jesus's anti-Jewish rhetoric to that of Adolf Hitler and Jesus's dealings with the poor (impoverishing their families by demanding the disciples abandon their families, while receiving the labor of his disciples in return for nothing but heavenly rewards) to those of Harold Camping, the American Fundamentalist Christian, who impoverished his followers with false prophecies about the doomsday. Chapters I I-I 3 treat Jesus in relationship to broader phenomena and institutions. In chapter I I, Avalos addresses Jesus's faith healing and practically identifies Jesus as a magician who assumes supernatural etymologies and cures when it comes to illnesses, and calls him "a bad Jesus by modern medical standards." In chapter I 2 , which addresses Jesus's environment ethics, the author in essence argues that Jesus is anthropocentric and utilitarian in his attitude to nature. Finally, in chapter I3, Avalos compares Jesus's use of the Old Testament unfavorably to that of Mel Gibson in the film The Passion of the Christ. He criticizes New Testament ethicists of applying double standards: when Gibson gets his facts wrong or blatantly misrepresents scripture, they call it irresponsible and dangerous use of scripture, whereas they view similar misuses of scripture by Jesus as a normal part of his cultural context. 
Whether or not one agrees with the author's conclusions, this book is the first systematic challenge to New Testament ethics by an atheist scholar firmly grounded in the Hebrew Bible and its ancient Near Eastern context and well-versed in New Testament and Early Christianity. The arguments that Avalos marshals in refuting the New Testament ethicists are certainly worth considering. Even his overall conclusion is not as shocking as it may sound at first. He simply argues that some of what Jesus said and did appear comfortably placed in the ist century Palestinian culture, but are contrary to the modern ethical sentiments enshrined in the UDHR. And he accuses the New Testament ethicists of attempting to make Jesus anachronistically modern. The following reflections are more concerned with meta-critical issues than with details of his exposition of scripture.

First, it is one thing to say that Jesus is not modern in his ethics, and quite another thing to say that Jesus is unethical or "bad." I also disagree with the author's assertion that it is unethical to rely on any text or any person, ancient or modern, to formulate ethics. Avalos should know that we do not formulate ethics ex nibilo. Our practical reason rests on certain a priori foundations. These include not only scientific facts but also what I would call "tradition"-namely, accumulated communal reflections on what it is to live as a human being under various circumstances-which has been transmitted to us in canonical literature. The UDHR is itself a product of practical reason interacting with scientific facts and various political-ethical traditions. Indeed, the Bible is one of those traditions. The ethics uprooted from or formulated independent of tradition is in danger of being utopian in its perspective. We need ethical principles that can empower an individual (living in less than ideal societies as most of us do) to lay the foundations for a more just and better society in the midst of a sea of injustice. The Bible helps us to understand the fallen condition of the world and helps us formulate ethical principles to enable us to do just that. The reason why Avalos considers it unethical to rely on the Bible or Jesus may relate to his a priori acceptance of modern science and democracy as the Greatest Good.

Second, the mere disproving of the portrayal of Jesus presented by New Testament ethicists does not make the author's portrayal of Jesus necessarily right. As he admits, it is extremely difficult to reconstruct the historical Jesus, so it is best to work with the Jesus of the Gospels. Then the issue becomes hermeneutical. Avalos is not entitled to call the opponents' position "unscientific" or "apologetic," because of their theistic presupposition, because his exegesis is also influenced by his own atheist presupposition. He also uses 
his scholarship as a tool to promote his own agenda. This may account for the "strange" fact that Avalos attacks New Testament ethicists as any fundamentalist would. To quote Lineham, "The result is wild exaggeration based on a very literal reading of the text." For instance, Avalos staunchly rejects other interpretive possibilities for the phrase "to hate one's father and mother and wife and children and brother and sister" in Luke I 4:26 and speculates that Jesus literally preached hatred among his disciples for his imperialistic agenda.

Third, the observation that Jesus never does anything wrong in academic literature of Christian ethics does not necessitate the conclusion that New Testament scholars are religionist. The consistently positive portrayals of Jesus by these scholars may be due to the generic nature of the Gospels. The Gospels are generically similar to Greco-Roman biography (bios), whose purpose is encomiastic, instead of being critical. The Gospel writers may have intended no negatives for Jesus in the first place, although the Jesus of the Gospels may appear to violate modern standards of ethics. If this is the case, it is only natural that biblical scholars who seek authorial meanings should consistently arrive at positive portrayals of Jesus.

These observations do not detract from the fact that Hector Avalos has rendered a great service to the academic community by writing this stimulating, informative, and yet undeniably controversial book and it deserves a close reading whether or not one agrees with the author's conclusion.

Koowon Kim

Reformed Graduate University, Seoul 